\title{
Morphological and physiological variation in Toona ciliata under water and salinity stress
}

\author{
Ramon Silveira de Andrade ${ }^{1}$ (iD) Marcio Carlos Navroski ${ }^{*}$ (D) \\ Mariane de Oliveira Pereira ${ }^{1}$ Alexandra Cristina Schatz Sá ${ }^{1}$ (iD
}

${ }^{1}$ Departamento de Engenharia Florestal, Universidade do Estado de Santa Catarina (UDESC), 88504-600, Lages, Santa Catarina, Brasil. E-mail: marcio.navroski@udesc.br. "Corresponding author.

ABSTRACT: The objective of this paper was to test the effects of water deficit, saturation and salinity in individuals of Toona ciliata. Seven treatments were tested: the control group, the complete suspension of irrigation, the permanent saturation of the pot soil and four doses of $\mathrm{NaCl}(50,100,200$ and $400 \mu \mathrm{mol})$. The experimental design was completely randomized, with 8 repetitions in each treatment. Physiologic evaluations were carried out during the experiment, and morphologic evaluations at the end. The plants were responsive to the applied stresses comparatively to the control group. Reductions were observed in morphological and physiological variables in all treatments under stress. All individuals under stress recovered slightly in the end of the experiment, and began to sprout again, representing a probable adaptation to the conditions.

Key words: Toona ciliata, water saturation, water deficit, salinity.

\section{Variação morfológica e fisiológica em Toona ciliata sob efeito de} estresse hídrico e salino

RESUMO: O trabalho teve como objetivo mensurar os efeitos de déficit hídrico, saturação e efeito da salinidade em mudas de Toona ciliata. Foram testados sete tratamentos: controle, suspensão completa de irrigação, saturação permanente do solo no vaso e quatro diferentes doses de $\mathrm{NaCl}(50,100,200$ e $400 \mu \mathrm{mol})$. O delineamento experimental utilizado foi inteiramente casualizado, com oito repetições. Foram realizadas avaliações fisiológicas ao longo do experimento e ao final, avaliações morfológicas. As plantas foram responsivas aos estresses aplicados comparativamente ao controle. Havendo redução em variáveis morfológicas e fisiológicas em todos os tratamentos sobre estresse. Todos os individuos sob estresse tiveram uma pequena recuperação ao final do experimento, iniciando a rebrotar, representando uma possível adaptação ao estresse.

Palavras-chave: Toona ciliata, saturação hídrica, déficit hidrico, salinidade.

\section{INTRODUCTION}

Amongst the tree species used for commercial production of wood that were introduced in Brazil, Toona ciliata M. Roemer var. australis, commonly known as Australian red cedar has stood out recently, having some characteristics of economic importance, such as a short growth cycle, good wood productivity and high value in both domestic and foreign markets. Originally from the tropical regions of Australia, according to SOUZA et al. (2010) it has adapted well in Brazil, having reported favorable edaphoclimatic conditions for developing itself, its main advantage over the native cedar from Brazil being the absence of attacks by Hypsipyla grandella, a plague that attacks the apical bud of Meliaceae, causing the forking of the tree trunk. Its wood, of noble use, is indicated for fine furniture manufacturing and construction work (ALBINO et al., 2011).

According to MELOTTO et al. (2019), the environment conditions in the majority of states in Brazil are more advantageous for forest plantations than most wood producing countries, but even then the choice of which species to introduce depends on a variety of factors, such as adaptability to the local conditions, its susceptibility to local diseases and pests, the invasive potential of the species, use of quality seedlings and adequate planning of the products that will come from the plantation. However, choosing species that have tolerance of stresses such as droughts, flooding or salinity is also of high importance.

Hydric deficit causes morphologic, physiologic and nutritional alterations, which have influence in the seedling's capacity to resist adverse 
conditions of its surroundings, and consequently, in its quality (LISAR et al., 2012). Water stress can be classified as water deficit, the lack of water in the soil, or as water saturation (overflow), the excess of water. The water deficit stress induces physiologic and biochemical alterations in plants; blocking cellular growth and photosynthesis, whilst altering respiration, those being the first effects to appear (VELÁZQUEZ \& HERNÁNDEZ, 2013).

Overflow is a stress factor normally caused by flooding in plantations, it consisting in the total saturation of the soil pores by water. This layer can be superficial or deep, which can cause the partial or total submersion of the plants. Hydric saturation reduces the availability of nutrients, the diffusion of $\mathrm{O}_{2}$ and cellular respiration, influencing the plant's hydric relations and impairing the biomass gain (NAJEEB et al., 2015). In plants, the excess of salt induces a stress, constituting a limiting factor to the distribution and productivity of the species (YILDIRIM et al., 2009).

Saline stress can cause low osmotic potentials and high cation concentrations, among other alterations that include compromising the opening and closing of stomate, slowing the growth of leaves and biomass production and lowering the relative water content, turgor pressure and hydric cellular potential (TOPPA \& BRAMBILLA, 2011).

Considering the Australian red cedar's potential in the forestry industry, and the importance of knowing the effects of different stresses in the development of plants, this present research aimed to evaluate the effects of hydric deficit, saturation and salinity in seedlings of Toona ciliata. The expected response from the individuals under stress was a reduction in the photosynthetic rate and lighter mass at the end of the experiment.

\section{MATERIALS AND METHODS}

The experiment was developed during October 2018 and February 2019, in the plant nursery of the University of the state of Santa Catarina, located in Lages, Santa Catarina, Brazil, whose coordinates are $27^{\circ} 47^{\prime} 33^{\prime \prime} \mathrm{S}$ e $50^{\circ} 18^{\prime} 4$ ' W, it has an approximate altitude of 900 meters. According to the Köppen classification, the climate of the city of Lages/SC is subtropical highland with uniform rainfall (Cfb-temperate). The annual average temperature is $15^{\circ} \mathrm{C}$, and the annual average precipitation fluctuates between 1300 and $1500 \mathrm{~mm}$. The temperature and relative air humidity during the experiment were $26{ }^{\circ} \mathrm{C}$ and $76,9 \%$, respectively. These values were collected inside the greenhouse, with a datalogger, gathering information every 10 minutes.

Toona ciliata seedlings, at around two months of age, were manufactured in the university's plant nursery. The sowing was made inside tubes of $180 \mathrm{~cm}^{3}$, containing a commercial substrate based in Pinus bark, with addition of $6 \mathrm{~g} \mathrm{~L}^{-1}$ of Osmocote ${ }^{\circledR}$ fertilizer, in 19-6-10 (NPK) formulation, characterized by its slow release of 4 to 5 months. The seedlings were kept in the nursery for approximately 120 days and then moved to a greenhouse, and kept there for 30 more days. As soon as the seedlings reached an average height of $25 \mathrm{~cm}$ (October 2018), they were transferred to vases with $10 \mathrm{~L}$ capacity. The vases were filled with soil from the region, classified as Cambissolo Húmico alumínico argiloso (Inceptisol). The seedlings received the conventional irrigation from the greenhouse (approximately 8 daily $\mathrm{mm}$ ) for 40 days. After this period the induction of the stress treatments began.

The experimental design was randomized; seven treatments were tested, each having eight repetitions, constituted by the plant in the vase. The treatments were as follows: a control group; suspension of irrigation (hydric deficit); saturation of the soil and application of the saline stress, in four different concentrations of $\mathrm{NaCl}(50,100,200$ and $\left.400 \mu \mathrm{mol} \mathrm{L}{ }^{-1}\right)$.

The plants under hydric deficit were allocated inside the greenhouse, without any irrigation, their vases were covered with plastic bags, to avoid accidental irrigation. For the saturation of the soil, the holes in the bottom of the vases were covered, and then they were filled with water all the way to the border, being monitored daily and irrigated in case of the water level lowering. The saline stress was inducted with the $\mathrm{NaCl}$ concentration $(50,100$, 200 and $\left.400 \mu \mathrm{mol} \mathrm{L}^{-1}\right)$ diluted in water. The solution was applied in the day before each photosynthesis measurement. These treatments were also removed from irrigation, being the saline solution, the only irrigation used. The control group was kept in the area, under conventional irrigation of $8 \mathrm{~mm}$ per day.

The biometric evaluations of height and stem diameter were realized in two different times, the first in the day of the stresses implementation and the second in the end of the experimental period, 36 days after. The data from those evaluations were utilized to obtain the height increment (IH), stem diameter increment (IDAC) and height/stem diameter ratio $(\mathrm{h} / \mathrm{d})$. Thirty days after the beginning of the experiment, a visual analysis of symptoms due to stress was made, grades ranging from 1 to 5 
were given to each plant, the grades were as follows: 1) normal; 2) spots in the leaves; 3) winding of the leaves 4) both previous symptoms in one plant and 5) leaf shedding.

Five plants from each treatment were selected for photosynthesis measuring, realized with a portable photosynthesis system IRGA (InfraRed Gas Analyzer), model LI-6400 (LI-COR). Five analysis were made, 3, 9, 16, 23 e 33 days after the induction of the stresses. Measurements were made between 8 and 10 AM in each day, keeping the randomness of treatments.

The following variables were measured with the IRGA: liquid photosynthetic rate $(\mathrm{A}-\mu \mathrm{mol}$ $\left.\mathrm{CO}_{2} \mathrm{~m}^{-2} \mathrm{~s}^{-1}\right)$, stomatal conductance ( $\mathrm{Gs}-\mathrm{mol} \mathrm{m}^{-2} \mathrm{~s}^{-1}$ ), transpiration $\left(\mathrm{E}-\mathrm{mmol} \mathrm{H}_{2} \mathrm{O} \mathrm{m} \mathrm{m}^{-2} \mathrm{~s}^{-1}\right)$, intercellular concentration of $\mathrm{CO}_{2}$ in the mesophyll $(\mathrm{Ci}-\mu \mathrm{mol}$ $\left.\mathrm{CO}_{2}\right)$ and external $\mathrm{CO}_{2}$ concentration $(\mathrm{Ca}-\mu \mathrm{mol}$ $\mathrm{CO}_{2}$ ). With those variables, the ratio of intercellular/ external concentration of $\mathrm{CO}_{2}\left(\mathrm{Ci} / \mathrm{Ca}-\mu \mathrm{mol} \mathrm{CO} \mathrm{CO}_{2}\right)$ and the water use efficiency of the plant (WUE - [ $\mu \mathrm{mol}$ $\left.\mathrm{m}^{-2} \mathrm{~s}^{-1}\right]^{-1}$ ) were estimated.

At the end of the experimental period, the dry mass of the plants was manually collected, by the destructive method. Samples were divided in root and shoot, which were then put inside paper bags, and kept inside a drying oven with forced air circulation (60 \pm 3 ${ }^{\circ} \mathrm{C}$ ) until reaching constant mass (grams) after 96 hours. After, they were weighed in a precision scale $(0,01 \mathrm{~g})$ in order to find out the ratio of dry mass in each plant. The Dickson quality index (IQD) was also estimated.

The normality of the data was ascertained with the Shapiro-Wilk test as was the homogeneity of variances with Bartlett's test. They were then submitted to an analysis of variance (ANOVA). And with significant $F$ values $(p<0,05)$, Tukey's range test $(p<0,05)$ was used to find the differences of means.

\section{RESULTS}

In relation to the morphologic variables (IH, IDAC, h/d ratio, visual analysis, dry mass and IQD) measured during the experiment, all of them had significant differences $(p$-value $<0.05)$ in the different treatments applied to the Australian red cedar plants, with the exception of $\mathrm{h} / \mathrm{d}$ ratio (Table 1 ).

Amongst the treatments, the tallest average of height increment was from the control group while the worst was the saline stress of $50 \mu \mathrm{mol}$ of $\mathrm{NaCl}$. The control group was the only treatment that was significantly different from the others. The control group was also the one with highest value in stem diameter increment, and the water deficit treatment had the worst average, in this variable, the control group was also the only to be significantly different than the rest. In the height/stem diameter ratio, there was no difference among the treatments.

In the visual analysis the control group had the best results, with an average grade of 1.0 (the smallest average being better). Both water saturation and deficit had the worst results, their averages both being 4.6. The control group was not statistically different from the 50 and $100 \mu \mathrm{mol} \mathrm{NaCl}$ doses, which themselves didn't differ from the 200 and 400 $\mu \mathrm{mol} \mathrm{NaCl}$ doses, the water saturation and deficit.

In relation to each treatment's dry mass, the highest average of shoot dry mass (MSA) belonged to

Table 1 - Morphologic variables obtained in the evaluation of Toona ciliata seedlings, according to the different stresses.

\begin{tabular}{|c|c|c|c|c|c|c|c|c|}
\hline \multirow[t]{2}{*}{ Treatment } & \multicolumn{8}{|c|}{ 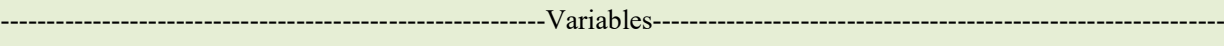 } \\
\hline & $\mathrm{IH}(\mathrm{cm})$ & IDAC $(\mathrm{mm})$ & $\mathrm{h} / \mathrm{d}$ & AV & $\operatorname{MSA}(\mathrm{g})$ & $\operatorname{MSR}(g)$ & $\operatorname{MST}(\mathrm{g})$ & IQD \\
\hline Control Group & $14.7 \mathrm{a}^{*}$ & $3.64 \mathrm{a}$ & $4.98^{\text {ns }}$ & $1 \mathrm{a}$ & $8.62 \mathrm{a}$ & $8.61 \mathrm{a}$ & $17.2 \mathrm{a}$ & $2.93 \mathrm{a}$ \\
\hline Saturation & $3.12 b$ & $1.38 \mathrm{~b}$ & 4.81 & $4.6 \mathrm{~b}$ & $2.83 b$ & $1.3 \mathrm{~b}$ & $4.13 b$ & $0.6 \mathrm{~b}$ \\
\hline Hydric deficit & $3.04 \mathrm{~b}$ & $0.84 \mathrm{~b}$ & 5.49 & $4.6 \mathrm{~b}$ & $3.14 \mathrm{~b}$ & $1.88 \mathrm{~b}$ & $5.02 \mathrm{~b}$ & $0.69 b$ \\
\hline $50 \mu \mathrm{mol} \mathrm{NaCl}$ & $2.94 b$ & $1.61 \mathrm{~b}$ & 4.75 & $3.2 \mathrm{ab}$ & $4.04 \mathrm{~b}$ & $2.62 b$ & $6.65 b$ & $1.06 \mathrm{~b}$ \\
\hline $100 \mu \mathrm{mol} \mathrm{NaCl}$ & $4.8 \mathrm{~b}$ & $1.58 \mathrm{~b}$ & 4.78 & $3 a b$ & $3.46 \mathrm{~b}$ & $2.78 b$ & $6.25 b$ & $1.05 \mathrm{~b}$ \\
\hline $200 \mu \mathrm{mol} \mathrm{NaCl}$ & $5.22 b$ & $1.04 \mathrm{~b}$ & 5.17 & $3.4 \mathrm{~b}$ & $3.4 \mathrm{~b}$ & $2.71 \mathrm{~b}$ & $6.11 \mathrm{~b}$ & $0.94 b$ \\
\hline $400 \mu \mathrm{mol} \mathrm{NaCl}$ & $3.34 \mathrm{~b}$ & $1.35 \mathrm{~b}$ & 4.75 & $2.6 a b$ & $2.88 \mathrm{~b}$ & $2.17 \mathrm{~b}$ & $5.04 \mathrm{~b}$ & $0.84 b$ \\
\hline
\end{tabular}

*Equal letters don't differ between treatments according to Tukey test at 5\% probability. ${ }^{\text {ns }}$ - no significant effect. Where: IH: Height increment; IDAC: Stem diameter increment; h/d: Height/diameter ratio; AV: Visual analysis of seedlings; MSA: Shoot dry mass; MSR: Root dry mass; MST: Total dry mass; IQD: Dickson quality index. 
the control group, it being different to all the other treatments. The same result happened in root dry mass (MSR), total dry mass (MST) and Dickson quality index (IQD).

In the physiological variables (photosynthetic rate, stomatal conductance, $\mathrm{Ci} / \mathrm{Ca}$ ratio, transpiration and water use efficiency), there was difference (p-value <0.05) between all stress treatments from the second evaluation onwards, 9 days after the first. The great effect of the stress in the saturation treatment can be observed in the behavior of the photosynthetic rate (Figure 1a). In the first evaluation (day 3 of the experiment) it was already possible to notice a reduction in its photosynthetic rate. In the ninth day a big difference among the treatments can be seen, with the control group maintaining similar values to the first analysis, while the majority of other treatments began to show stress signals, highlighting the hydric saturation and deficit treatments.

The third and fourth evaluations (16 and 23 days after the start respectively) presented a similar behavior, in which the control group kept its photosynthesis values close to the first two, while the others continued to decrease. In the last evaluation (day 33 of the experiment), the control group was once again the one with highest values. The saline stress treatments with 50,100 and $200 \mu \mathrm{mol} \mathrm{NaCl}$, recovered their photosynthetic rate from the previous analysis (23 days).

In the first evaluation, all treatments were similar for stomatal conductance (Figure 1b). In the ninth day, the stress signals began to appear in some treatments, the control group had the best conductance, not differing from the 50 and $100 \mu \mathrm{mol}$ $\mathrm{NaCl}$ treatments. The water saturation treatment had the worst conductance values. The last three evaluations, in days 16, 23 and 33, had similar behavior, the control group staying on top and now differing from all others. In the last evaluation all treatments except the water saturation recovered the conductance slightly.

In the first evaluation for $\mathrm{Ci} / \mathrm{Ca}$ ratio, all treatments were statistically similar (Figure 1c). In the second, the hydric deficit treatment began to drop, showing the worst ratio and being the only one to differ significantly from the best (control group). In the evaluation from day 16, the control group kept the best $\mathrm{Ci} / \mathrm{Ca}$ ratio, maintaining that in all later analysis. All treatments recovered the ratio in the last analysis.

In day 3 of the experiment, all treatments were close in transpiration. With 9 days, it was possible to notice significant differences, with the saturation treatment having the worst value (Figure 1d). The last three evaluations had similar behavior, the control group in all three had the best transpiration, both saturation and saline dose of $100 \mu \mathrm{mol} \mathrm{NaCl}$ had significant recovery in the last analysis.

The first evaluation had similar values for all treatments in water use efficiency (Figure 1e). The control group had stable behavior in WUE during all analysis. Both water and saline stress treatments elevated the most in the intermediate evaluations (days 16 and 23) and fell back to values close to the ones from the beginning after a month passed from the application of the stresses.

\section{DISCUSSION}

The application of the stresses resulted in contrasting effects in all cases, hydric deficit being the one who yielded the biggest symptoms, exemplified by the small increment in height, smaller dry mass and IQD value, and worst grade in visual analysis. In the physiological variables, the effect in this treatment was also fast and easily seen, its photosynthetic rate among the smallest right from the beginning, decreasing even more during the experiment.

This effect in the seedlings is a consequence of the limitation in the carbon assimilation from the photosynthesis. A detail that can be highlighted from the treatment was the precocious loss of leaves, which is an eventual response to the hydric deficit (MAFAKHERI et al., 2010). Hydric stress usually affects the leaf area and leaf mass (VON ARX et al., 2012). The water deficit promoted smaller biomass production in all parts of the plant; however, it also had bigger water use efficiency, because with the reduction in leaf area there was a lesser loss of water, therefore the carbon/transpiration ratio was positive (CERNUSAK et al., 2011).

In the same way, the effects of the stress were fast in the soil saturation treatment, it, alongside with the deficit treatment being the treatments with most symptoms, and in general the more intense effects. Its photosynthetic rate was the smaller among the treatments from the start, the stress effects noticeable from the beginning, maintaining the smallest value until the end of the experiment. Its stomatal conductance, $\mathrm{Ci} / \mathrm{Ca}$ ratio, and transpiration had similar behaviors, starting the experiment among the smaller values, significantly reducing until the middle and recovering in the end of it.

Saturated soils inhibit root growth, leaf area expansion, and photosynthesis because of the lack of oxygen and cooler soil temperatures. Yellow 




leaves indicated a slowing of photosynthesis and plant growth. Leaves and sheaths may turn purple from accumulation of sugars if photosynthesis continues but growth is slowed (BASU et al., 2016).

Although, root growth can compensate to some extent later in the season, a saturated profile early in the season can confine the root system to the top several inches of soil, setting up problems later in the season if the root system remains shallow.
Plants with shallow root systems also become more susceptible to stand ability problems during periods of high winds (BASU et al., 2016).

In these cases, abscisic acid, ethylene and its precursors can form in large quantities, which would cause the closing of stomata in leaves, a hyponastic response and frequently leaf abscission. Insuccession, the membrane cellular system degenerates, mitochondria are disintegrated and their enzymes are 
partially inhibited (LARCHER et al., 2016), decreasing the growth and development of plants.

The effects of stress were also notable in the saline stress treatments, in less quantity than both hydric ones however, indicating the species bigger resistance to this type of stress. According to FATEMI et al. (2019), responses in gene expression of related genes may lead to mechanisms of ionic and osmotic homeostasis, growth control and repair of cell damage. Taken together, these responses may result in the plant's tolerance or sensitivity to stress.

The treatments under stress had similar behavior during the evaluation of the physiological variables, bottoming (peaking in the case of water use efficiency) around the $21^{\text {st }}$ day, and recovering afterward, in some cases ending the experiment close to the control group again, showings a possible adaptation to the conditions they were under. Contributing to this, is the fact that during the recover, some individuals started to sprout again.

\section{CONCLUSION}

Observing the analysis results, it can be noticed that the Toona ciliata seedlings are susceptible to all three stress types that were applied. Plants under the effect of hydric deficit and saturation were affected earlier and in a more expressive way, indicating that the species might suffer more in flooded soils, or in cases with rain deficit. In the case of hydric saturation, the symptoms were faster to appear. As for the saline stress, the symptoms were milder and slower to appear, which might indicate the species has a certain capacity to adapt to saline soils.

\section{ACKNOWLEDGEMENTS}

The authors thank the Universidade do Estado de Santa Catarina (UDESC), for the institutional support for this research. To FAPESC for funding the research group Management of Planted and Natural Forests (PAP2019031000055) and Coordenação de Aperfeiçoamento de Pessoal de Nível Superior (CAPES) for partial finance support, Brasil - Finance code 001.

\section{DECLARATION OF CONFLICT OF INTEREST}

The authors declare no conflict of interest. The founding sponsors had no role in the design of the study; in the collection, analyses, or interpretation of data; in the writing of the manuscript, and in the decision to publish the results.

\section{AUTHORS' CONTRIBUTIONS}

The authors contributed equally to the manuscript. All authors critically revised the manuscript and approved of the final version.

\section{REFERENCES}

ALBINO, V. C. do S. Avaliação das propriedades físico-mecânicas de painéis compensados de Toona ciliata M. Roem. var. australis. Cerne, v.17, p.103-108, 2011. Available from: <http://www.scielo. br/pdf/cerne/v17n1/v17n1a12.pdf>. Accessed: Feb. 23, 2020. doi: 10.1590/S0104-77602011000100012.

BASU, S. Plant adaptation to drought stress. F1000Research, v.5(F1000 Faculty Rev):1554. Available from: <https:// www.ncbi.nlm.nih.gov/pmc/articles/PMC4937719/pdf/ f1000research-5-8268.pdf $>$. Accessed: Dec. 11, 2019. doi: 10.12688/f1000research.7678.1.

CERNUSAK, L.A. et al. Responses of legume versus non legume tropical tree seedlings to elevated $\mathrm{CO}_{2}$ concentration. Plant physiology, v.157, p.372-385, 2011. Available from: <http://www. plantphysiol.org/content/157/1/372>. Accessed: Apr. 10, 2019. doi: $10.1104 /$ pp.111.182436.

FATEMI, F. Exploiting differential gene expression to discover ionic and osmotic-associated transcripts in the halophyte grass Aeluropus littoralis. Biological Procedures Online, v.21, p.116, 2019. Available from: <https://link.springer.com/content/ pdf/10.1186\%2Fs 12575-019-0103-3.pdf>. Accessed: Dec. 03, 2019. doi: 10.1186/s12575-019-0103-3.

LARCHER, M.V. et al. Ku Binding on telomeres Occurs at Sites Distal from the Physical Chromosome Ends. PLoS Genet, v.12, 2016. Available from: <https://journals.plos.org/plosgenetics/ article?id=10.1371/journal.pgen.1006479>. Accessed: Apr. 15, 2019. doi:10.1371/journal.pgen.1006479.

LISAR, S.Y.S. et al. Water Stress in Plants: Causes, Effects and Responses. InTech, v. Water Stress, p.1-14, 2012. Available from: $<$ https://www.intechopen.com/books/water-stress/water-stress-inplants-causes-effects-and-responses>. Accessed: Apr. 15, 2019. doi: $10.5772 / 39363$.

MAFAKHERI, A. et al. Effect of drought stress on yield, proline and chlorophyll contents in three chickpea cultivars. Australian journal of crop Science, v.4, p.580-585, 2010. Available from: $<$ http://edepot.wur.nl/159961>. Accessed: Jan. 10, 2019.

MELOTTO, A. M. et al. Forest species in integrated production systems. In: BUNGENSTAB, D. J. et al. ILPF: innovation with crop, livestock and forest integration. Brasília, Df: Embrapa, 2019. Cap. 27. p. 429-454. Available from: <https://www.alice. cnptia.embrapa.br/handle/doc/1112938>. Accessed: Dec. 04, 2019.

NAJEEB, U. et al. Consequences of waterlogging in cotton and opportunities for mitigation of yield losses. AoB Plants. v.7, 2015. Available from: <https://www.ncbi.nlm.nih.gov/pmc/articles/ PMC4565423/>. Accessed: May, 19, 2019. doi: 10.1093/aobpla/plv080.

SOUZA, J. C. A. V. de; BARROSO, D. G.; CARNEIRO, J. G. de A. Cedro australiano (Toona ciliata). Niterói, RJ: Rio Rural, 2010. 14 p. 
TOPPA, E.V.B.; BRAMBILLA, W.P. Melhoramento de plantas e a salinidade dos solos. Revista Verde, v.6, p.21-25, 2011. Available from: $\quad<$ https://www.gvaa.com.br/revista/index.php/RVADS/ article/view/430/551>. Accessed: fev. 22, 2019.

VELÁZQUEZ, S.F.; HERNÁNDEZ, V.E.B. Abiotic Stress in Plants and Metabolic Responses. InTech, p.25-48, 2013. Available from: <https://www.intechopen.com/books/abioticstress-plant-responses-and-applications-in-agriculture/abioticstress-in-plants-and-metabolic-responses $>$. doi: 10.5772/54859.
VON ARX, G. et al. Long-term functional plasticity in plant hydraulic architecture in response to supplemental moisture. Annals of Botany, v.109, p.1091-1100, 2012. Available from: $<$ https://www.ncbi.nlm.nih.gov/pubmed/22396436>. Accessed: Feb. 02, 2019. doi: 10.1093/aob/mcs030.

YILDIRIM, E. etal. Mitigation of salt stress in strawberry by foliar K, Ca and Mg nutrient supply. Plant, Soil and Environment, v.55, p.213-221, 2009. Available from: <https://www.agriculturejournals.cz/publicFiles/07200. pdf $>$. Accessed: Feb. 04, 2019. doi: 10.17221/383-PSE. 